\title{
To Warn or Not to Warn? Genetic Information, Families, and Physician Liability
}

\author{
Jennifer L. Gold*, BSc, BCL
}

\begin{abstract}
Genetic testing raises a number of legal issues. Physicians providing genetic testing may be faced with questions related to privacy, confidentiality, and the duty to warn. Because genetic information is by its very nature familial, genetic test results may have implications for others not privy to the particular physician-patient relationship. This can result in a legal and ethical quandary for the treating physician. This paper addresses questions with respect to genetic testing and the legal obligations of physicians. First, can a physician legally breach doctor-patient confidentiality to inform a family member of a genetic risk? Second, does the physician have a duty to warn the interested third party of that risk? And if the physician fails to warn that party, could s/he be found liable? These questions are addressed here in a comparative fashion, examining Canadian (and, where appropriate, American) common law as well as Quebec civil law. The paper concludes that physicians should be liable for the duty to warn in the context of genetic information only when the risk is serious, imminent, and avoidable.
\end{abstract}

Ever since Watson and Crick deciphered the doublehelix structure of DNA in 1953, genetic technology has been extolled, criticized, and debated. For example, the increasing availability of genetic tests for certain diseases--for example, Huntington's disease-- is viewed by many as a positive development in genetics. Others, however, question the value of predictive testing for such diseases, many of which currently have no effective treatments. With respect to the legal context, genetic testing raises a host of new issues. Physicians providing genetic testing may be faced with questions related to privacy, confidentiality, and the duty to warn. Because genetic information is often by its very nature familial, genetic test results, unlike the results of some other medical tests, may have implications for others not privy to the particular physician-patient relationship. This can result in a legal and ethical quandary for the treating physician.

This paper will address two interrelated questions with respect to genetic testing and the legal obligations

*To whom correspondence should be addressed: Jennifer L. Gold, 203 Park Drive \#214 Boston, MA 02215

email: jgold@hsph.havard.edu of physicians. First, can a physician legally breach doctor-patient confidentiality to inform a family member of a genetic risk? Second, does the physician have a duty to warn the interested third party of that risk? And if the physician fails to warn that party, could s/he be found liable? These questions will be addressed in a comparative fashion, examining Canadian (and, where appropriate, American) common law as well as Quebec civil law.

\section{GENETIC TESTING AND INFORMATION}

There are several different types of genetic testing, all of which "use a variety of laboratory techniques to determine if a person has a genetic condition or disease or is likely to get the disease"(1). The first type of testing is prenatal genetic diagnosis (1). Tests such as amniocentesis or chorionic villus sampling can provide information on the genetic makeup of the fetus, such as whether it has Down's Syndrome (i.e., trisomy 21)(2). A second type of testing is newborn screening for specific diseases (1). All babies are screened at birth for phenylketanuria, a potentially serious condition for which early diagnosis and intervention is essential. The 
third type of genetic testing is carrier testing, which involves the testing of couples planning to have children who may carry the genes for certain recessive disorders(1). For example, carrier testing for Tay-Sachs disease, a devastating and fatal neurological disorder, is recommended for Ashkenazi Jews, a population with a high incidence of Tay-Sachs. The fourth and final type of genetic testing available is for late-onset disorders, such as the aforementioned Huntington's (1). It may also provide information on a person's predisposition and susceptibility to heart disease or certain cancers-for example, a propensity for breast cancer in patients who carry the mutated BRCA gene. Genetic testing can have important consequences for those who choose to undergo it. In testing for late-onset disorders, for example, predictive testing can assist people in making decisions about medical care. Further, prenatal genetic testing can lessen a couple's uncertainty regarding their baby's genetic health, or help them make decisions about whether or not to continue a pregnancy.

The information obtained via genetic testing can be seen to differ from the medical information acquired from other clinical tests in that it is familial in nature. Whereas many clinical tests provide results that could be considered relevant only to the individual in question-for example, one's blood sugar or hemoglobin levels-genetic test results have the potential to uncover information that is important to an entire group of people. For example, if one woman in a family is found to have a BRCA1 mutation, this information may be relevant to her mother, daughters, sisters, cousins, or aunts. In such a situation, what are the legal obligations and ethical responsibilities of the treating physician? In response to this conundrum, scholars such as Dorothy Wertz have advanced theories of "family property" with respect to genetic information (3). They propose that because of the interconnectedness of families' genetic material, the physician's "patient" is the family in its entirety, and not just the individual him or herself (3). Such a position eliminates the confidentiality problem, as the family is made privy to the doctor-patient relationship. However, although this is an interesting proposition, it has yet to be fully embraced by the courts or the legislatures. It is therefore necessary to examine issues related to confidentiality and duty, though bearing in mind this special, familial nature of genetic information.

\section{MEDICAL CONFIDENTIALITY AND ITS EXCEPTIONS}

Sources of the Duty of Confidentiality

Physicians have a duty of medical confidentiality. Maintaining confidentiality respects the autonomy and privacy of the patient, and encourages a relationship of trust between the patient and his/her physician. The duty of confidentiality has numerous sources, including "the common law, principles of equity, various statutory provisions, and in the ethical codes governing health care professionals" (4). Concerning jurisprudence, the leading case on confidentiality in Canada is McInerney v. Macdonald (5). In that case, the Supreme Court held that the relationship between the doctor and his/her patient is "fiduciary in nature", meaning that an obligation of confidentiality stems from their special relationship. A patient may therefore expect that information disclosed during the course of a medical appointment is privileged, a matter between oneself and one's physician.

With respect to statutory requirements for medical confidentiality and privacy, on January 1, 2001, the Personal Information Protection and Electronic Documents Act came into effect in Canada (6). This federal legislation "sets out ground rules for how private sector organizations may collect, use or disclose personal information in the course of commercial activities" (7). The act was expanded to specifically include personal health information one year later, on January 1, 2002. There are also provincial statutes protecting privacy. For example, confidential medical information in Manitoba is protected by the Personal Health Information Act (8). The Act applies to all "health professionals, health care facilities, public bodies and health services agencies that collect or maintain personal health information" (9). Similarly, in Quebec, health information is protected by the Act respecting access to documents held by public bodies and the protection of personal information, and the Act respecting the protection of personal information in the private sector $(10,11)$. The latter, for example, clearly states that "No person may communicate to a third person the personal information contained in a file he holds on another person, or use it for purposes not relevant to the object of the file, unless the person concerned consents thereto" (11). These statutes are relevant to the doctor-patient relationship, in that they specify the standards of privacy and confidentiality to which a physician must adhere with respect to medical information. These Acts stipulate that physicians must not communicate the private medical information of their patients to third parties without prior consent.

A third source of the duty of confidentiality are professional codes of ethics. For example, the Canadian Medical Association (CMA) Code of Ethics states that physicians must respect their patients' right to confidentiality, except where provided by law--for example, when there is "significant risk of substantial harm to others" (12). Even in such situations, however, the Code stipulates that every effort must be made to 
inform the patient of the impending breach of confidentiality.

\section{Exceptions to Confidentiality}

There are both statutory and jurisprudential exceptions to the confidentiality rule. With respect to statutes, provincial public health legislation often requires physicians to report certain communicable diseases. The Ontario Health Protection and Promotion Act, for example, provides that

\footnotetext{
A physician who, while providing professional services to a person, forms the opinion that the person is or may be infected with an agent of a communicable disease shall, ... report thereon to the medical officer of health of the health unit in which the professional services are provided (13).
}

AIDS, all types of food poisoning, and meningitis are examples of reportable diseases in Ontario (14). Highly contagious diseases such as bacterial meningitis, moreover, must be reported immediately to public health authorities. Child welfare legislation is another example of a statutory exemption to medical confidentiality. Physicians who suspect a child is being abused are required to report this information immediately to the appropriate child protection authorities.

With respect to the existing jurisprudence on exceptions to confidentiality, Flanagan points out that in McInerney, the Supreme Court of Canada clarified that the right of patients to confidentiality "is absolute unless there is some paramount reason that overrides it" (4). This would include, according to the Court, situations in which the "physical or moral" safety of other individuals or the public is in danger (5). Other cases which confirm the necessity of overriding doctorpatient confidentiality in situations where there is a danger to others are those which deal with the "duty to warn" in the psychiatric context. These will be examined in detail below under the discussion on the physician's duty to warn.

\section{Can a Physician Breach Confidentiality to Reveal Genetic Information to a Relative?}

It is possible that, should a patient refuse to reveal genetic information to relatives that the doctor believes is important to their health and well-being, the doctor may feel s/he has the duty to report this information to the family nonetheless ${ }^{2}$. In such a situation, is it likely that a court would find the physician liable for a breach of medical confidentiality? American cases have suggested that in certain situations, disclosing private information to relatives may be permissible. With respect to spouses, in several cases American courts have held that disclosure of one partner's medical records to the other is not a violation of privacy, even if the couple is in the midst of divorce proceedings (1517). The decisions in such cases tended to center on the idea of each spouse having the right to know of any disease that may have an impact on the marital relationship. However, other cases have recognized that medical information is confidential and privileged even in the marital context $(18,19)$. In MacDonald $v s$. Clinger, for example, the judge held that psychiatric information should be entitled to very a very high standard of privilege, as an individual may seek psychiatric help for problems associated with the marital relationship $(19,20)$. Spousal disclosure is relevant to genetic confidentiality because of its implications for reproduction. If one spouse is carrying, for example, the cystic fibrosis gene, this may be considered pertinent to the other spouse if the couple is attempting to conceive a child.

With respect to siblings, Suter indicates that (American) courts are "more likely to be reluctant to disclose medical information to siblings than to a spouse" (20) This was the case in Diderikx v. Cottage Hospital Corp, an obstetrics medical malpractice suit in which the court held that the medical records of the infant's sibling could not be disclosed (21). Suter hypothesizes that courts may be more hesitant in releasing confidential medical information to siblings because "one presumes less intimacy exists among siblings". She also notes, however, that in Diderikx, the records were requested "only for the benefit of litigation, which might be deemed a less pressing interest than disclosure for the benefit of making reproductive decisions".

Applied to the Canadian context, it is possible that a physician may be excused by the court for breaching confidentiality to inform a family member of a genetic risk. The Manitoba Personal Health Information Act section 22 (8) permits the disclosure of personal medical information without an individual's consent if such disclosure is "necessary to prevent or lessen a serious and immediate threat to the mental or physical health or the safety of the individual the information is about or another individual." Such an exception would seem to permit disclosure if the genetic information could be considered "a serious and immediate threat" to the family member. Similarly, in Quebec, the Act respecting the protection of personal information in the private sector indicates at section $18(7)$ that: A person carrying on an enterprise may, without the
consent of the person concerned, communicate personal
information contained in a file he holds on that person...to
a person to whom the information must be communicated 
by reason of the urgency of a situation that threatens the life, health or safety of the person concerned (11).

Like the Manitoba provision, the Quebec statute also makes an exception for the non-consensual disclosure of information to a third party if the matter is urgent and concerns health and safety.

The question therefore turns on what the courts would consider an "urgent" or "serious and immediate" threat to another's health and safety. Commentator William Flanagan questions "whether a genetic risk is of sufficient weight to...grant a privilege of disclosure" (4). The existing cases, as mentioned above, concern mainly psychiatric patients who presented a foreseeable threat of violence to others. The communication of genetic information lacks the urgency of a breach of confidentiality communicating a threat of violent behavior or highly contagious disease. It is probable therefore that such cases would need to be evaluated in a casuistic fashion. In the event of a court decision on the matter, then, it would be important to determine how serious and urgent the particular situation was. For example, communicating the risk of malignant hyperthermia, a genetic condition which causes fatal reactions to general anesthesia, may be considered serious and urgent, whereas communicating a potential predisposition to certain types of cancer may not.

\section{GENETIC INFORMATION AND THE DUTY TO WARN}

\section{The Duty to Warn}

Closely related to the idea of breaching confidentiality is the duty to warn. Elliott writes that "hospitals, psychiatrists, social workers, and police have all been found, in some circumstances, to have a duty to warn someone they can identify as being at risk of harm, which can extend so far as to revealing information that there is a compelling interest in keeping confidential" (22). The most famous duty to warn case is Tarasoff $v$ Regents of the University of California, which was decided by the California Supreme Court (23). The case concerned a student who had revealed to his psychotherapist that he intended to kill a fellow student. The therapist failed to warn the woman of the patient's threat, and she was subsequently murdered. The Court held that a doctor or therapist "bears a duty to use reasonable care to give threatened persons such warnings as are essential to avert foreseeable danger arising from his patient's condition or treatment", and found the therapist liable (23).

Miller writes that the application of Tarasoff in Canada is possible in view of two Alberta decisions (24). In Tanner v. Norys, the Court of Appeal of Alberta stated that if a psychiatrist failed to warn a third party of a threat to her posed by a patient, the psychiatrist would be found liable as per Tarasoff (25). Similarly, in Wenden v. Trikha, the judge adopted the Tarasoff ruling in an obiter dictum ${ }^{3}$ (26). He indicated that hospitals and psychiatrists aware of a threat posed by a patient to a third party have a duty to protect that person if sufficient proximity exists between the third party and the patient. Another case which suggests a duty to warn at common law is Pittman v Bain (27). In that case, a physician failed to inform his patient the patient was HIV positive. As a result, the patient's wife contracted the virus. The doctor was found negligent for failing to warn not only Mr. Pittman, but also Mrs. Pittman, a third party.

In 1999, the Supreme Court of Canada handed down its decision in the case of Smith v Jones (28). The case concerned the issue of solicitor-client privilege. Dr. Smith had been retained as a psychiatrist by Mr. Jones' lawyer. Mr. Jones was charged with sexually assaulting a prostitute, and he confided to Dr. Smith that he had fantasies of raping and killing prostitutes. Dr. Smith found him to be a danger to society. Counsel for the accused, however, requested that he keep this matter confidential as per solicitor-client privilege. Dr. Smith subsequently brought an action requesting permission to disclose the information.

The Court held that Dr. Smith was required to disclose the relevant information. It stated that solicitorclient privilege "is the highest privilege recognized by the courts. By necessary implication, if a public safety exception applies to solicitor-client privilege, it applies to all classifications of privileges and duties of confidentiality" (28). The Court did not outline the specific steps to take in actually disclosing the information, suggesting that the appropriate person to notify--for example, the third party themselves, the authorities, etc--may vary from case to case (28). While Tarasoff was mentioned, it was not applied. The Court did, however, lay out a test for determining when it would be appropriate to breach confidentiality. It stated that

Three factors should be taken into consideration in determining whether public safety outweighs solicitorclient privilege: 1 . Is there a clear risk to an identifiable person or group of persons? 2. Is there a risk of serious bodily harm or death? 3 . Is the danger imminent? These factors must be defined in the context of each situation and different weights will be given to each, and to the various aspects of each, in any particular case (28).

Smith $v$ Jones therefore indicates that there is a duty to warn in cases where there is a clear and serious threat to others. As indicated above, this duty would clearly apply to doctor-patient confidentiality, as solicitor- 
client privilege is the highest form of privilege recognized by the courts.

With respect to statutory requirements for the physician's duty to warn, these are limited in the common law provinces to public health legislation requiring the reporting of certain infectious diseases, child welfare legislation, and highway and traffic laws mandating the reporting of unsafe drivers $(29,30)$. In Quebec, however, it may be possible to read a duty to warn into section 2 of the Quebec Charter of Human Rights and Freedoms (31). Section 2 stipulates that "every human being whose life is in peril has a right to assistance" (31) and that "every person must come to the aid of anyone whose life is in peril" (31). In the event of a danger to a third party, therefore, it is likely that a physician's duty to warn is mandated by the Quebec Charter.

\section{Duty to Warn in the Context of Genetics: Case Law}

Two American cases have examined the duty to warn with respect to genetics. In Pate v. Threlkel, Heidi Pate brought an action against the physician who had treated her mother for medullary thyroid carcinoma several years previously (32). She claimed that because that form of cancer is a genetically inheritable disease, the physician should have warned her or her mother of this fact. Ms. Pate alleged that had she known of the heritability of the cancer, she would have been tested and taken preventative action. The Florida Supreme Court held that a physician may have, in certain circumstances, a duty to warn a patient of the genetic inheritability of his or her disease. With respect to the claims of Ms. Pate, the court agreed that the physician had a duty to inform her mother that her children may have the same condition. The court also acknowledged that this duty may extend to members of the patient's family, as it is foreseeable that they would benefit from this information. However, the court declined to impose a duty on physicians to seek out family members, reasoning that such a duty could be satisfied by informing the patient his or herself.

Safer v. Pack dealt with a similar claim, but the Court came to a different conclusion (33). In 1990, Donna Safer was diagnosed with familial adenomatous polyposis (a form of colon cancer), the same disease her father had been treated for 34 years previously. Ms. Safer and her husband brought an action against the estate of the treating physician, claiming that because cancerous polyposis is a hereditary disease, and the physician knew this, he had a duty to warn those at risk. The Superior Court of New Jersey held that the physician had a duty to warn the patient and his family of the heritability of the colon cancer. While it did not specify how the duty to warn should be discharged, the
Court recognized that in some circumstances it may not be accomplished by simply warning the patient. Rather, a breach of doctor-patient confidentiality may be necessary. Therefore, in holding that there is a specific duty to family members that may require more than just warning the patient, the New Jersey court differed from the conclusions of the Florida court in Pate.

\section{Is There a Duty to Warn Family Members in Canada?}

To date, Canadian courts have not been faced with the question of physician liability for failing to warn a family member of a genetic risk. However, it is possible in light of both the American cases described above and the general duty to warn cases that have been decided in Canada, that courts may impose a duty to disclose genetic information to relatives. Considering the nature of the Canadian decisions, however, it would seem that those circumstances would be rare. In Smith (28), the Supreme Court held that there must be a risk of serious bodily harm or death, and that the danger must be imminent. Similarly, the psychiatric cases tend to focus on the threat of violence on the part of the patient. As mentioned above, it is unclear that genetic information could satisfy these conditions. First, many genetic tests provide information that is probabilistic and imprecise. For example, current genetic screening for Alzheimer's disease is inexact with respect to the various mutations associated with the disease, and may fail to adequately account for the effects of ethnicity, environment, and lifestyle (34). Further, from the legal perspective of the physician the risk is not immediate; there is no "urgency" as there would be in the context of a violent individual or an infectious disease. No timeline can be discerned from such a genetic test. The necessity of breaching confidentiality to reveal such information is therefore questionable.

Second, even if a genetic risk were to be considered serious and urgent enough to breach confidentiality, it would seem important to consider whether there exists a clear benefit to revealing this information. Underlying the decisions in Smith, Tanner, Wenden, and Bain is the idea that disclosing the confidential information in question will benefit and protect the third party at risk. With respect to the revelation of genetic information, the benefits are less clear. A disease such as Huntington's, for example, is incurable. While a third party could, theoretically, benefit from having this information with respect to reproductive choices, there remains some doubt as to whether revealing this information is clearly beneficial. Therefore, regarding genetic information, it is important to consider whether there exist clear, concrete benefits to revealing test results to a third party. 
Further, genetic information should be disclosed in a manner that is mindful of its potential psychological and emotional impact. If the physician in question is not the family member's physician, then, there is the additional problem of ensuring that there is adequate social and psychological support in place for the person. The physician should also bear in mind the fact that the person in question may not want to know this information. The privacy rights of family members, as the potential harm the information itself may cause, should therefore be considered before any disclosure takes place.

In 1983, the President's Commission for the Study of Ethical Problems in Medicine and Biomedical and Behavioral Research set out guidelines for the disclosure of genetic information (35). They identified four conditions that should be filled before a health care professional can breach confidentiality and disclose genetic information to at-risk relatives:

1. Reasonable efforts to elicit voluntary consent have failed.

2. There is a high probability that harm will occur if the information is withheld, and the disclosed information will actually be used to avert harm.

3. The harm that would result to identifiable individuals would be serious.

4. Appropriate precautions are taken to ensure that only the genetic information needed for diagnosis and/or treatment of the disease in question is disclosed.

These requirements fit the criteria set out in the Canadian jurisprudence, and elucidate how to apply the ideas to the genetics context. As in the case law, the criteria insist on serious harm, a high probability of that harm occurring, identifiable at-risk individuals, and benefits accruing from the disclosure of information. These guidelines could help to ensure that breaches of confidentiality and disclosure would occur only if necessary. As discussed above, most genetic information would likely not be considered to pass this test. Only if the risk of harm is great, avoidable, and, according to Canadian jurisprudence, immediate--such as the aforementioned malignant hyperthermia--would the information be disclosed. While these guidelines are not law, they have been adopted by the Science Council of Canada, and provide an ethical framework within which the physician can operate and make decisions regarding disclosure $(4,36)$.

\section{COMMENTS \& CONCLUSION}

The line between genetic and non-genetic information is increasingly blurred. As science uncovers genetic sources for more and more diseases, it may become difficult to separate genetic data from ordinary medical information. This could create a serious problem if physicians are found liable for failing to warn family members of genetic risks, creating a blanket duty to warn. It must be remembered that genetic information, while unique in that it is familial in nature, is nonetheless medical information subject to doctor-patient confidentiality.

Finally, it is perhaps important to mention that creating exceptions for genetic information reinforces ideas of genetic reductionism in our society, giving greater weight to genetic information than perhaps is warranted. As indicated above, merely possessing certain genes does not guarantee one will develop a disease. Similarly, not having particular genes does not guarantee one will not fall ill. Many factors other than our genotypes influence our health. By giving special treatment to genetic information, we may inadvertently encourage the neglect of environmental and lifestyle factors in the development of disease. In light of this fact, it is important that physicians be liable for the duty to warn in the context of genetic information only when the risk is serious, imminent, and avoidable.

\section{REFERENCES}

1. Lawrence Berkeley National Library. What is Genetic Testing? Accessed $10 \quad$ March 2004. http://www.lbl.gov/Education/ELSI/Frames/genetic-testingf.html

2. Roy DJ, William JR, Dickens BM. Bioethics in Canada. Scarborough: Prentice Hall Canada, 1994.

3. Wertz DC, Fletcher JC, Berg K. Guidelines on Ethical Issues in Medical Genetics and the Provision of Genetic Services. Geneva: WHO, 1995.

4. Flanagan W. Genetic Data and Medical Confidentiality. Health Law Journal 3: 269; 1995.

5. McInerney v. MacDonald [1992] 2 S.C.R. 138.

6. Privacy Commissioner of Canada. Privacy Legislation in Canada. Accessed $10 \quad$ March 2004. http://www.privcom.gc.ca/fs-fi/02_05_d_15_e.asp

7. Personal Information Protection and Electronic Documents Act, Statutes of Canada 2000, c.5.

8. Personal Health Information Act, S.M. 1997, c. 51.

9. Ombudsman Manitoba, Access and Privacy Division. The Personal Health Information Act. Accessed 10 March 2004. http://www.ombudsman.mb.ca/phia.htm.

10. R.S.Q., chapter A-2.1.

11. R.S.Q., chapter P-39.1.

12. Canadian Medical Association. Code of Ethics of the Canadian Medical Association, 1996. Accessed 10 March 2004. http://www.cma.ca/cma/common/displayPage.do?pageId=/stati cContent/HTML/N0/12/where_we_stand/1996/10-15.htm.

13. R.S.O. 1990 , c. H.7, s. 26.

14. Ontario Regulations 559/91, and amendments under the Health Protection and Promotion Act. 2003.

15. Pennison v Provident Life and Accident Insurance Company, 154 So. 2d 617 (La. Ct. App. 1963), certa. Denied 156 So. 2d 266)

16. Mikel v Abrahams, 541 F. Supp. 591 (W.D. Mo. 1982)

17. Curry v. Corn, 277 N.Y.S. 2d 470 )N.Y. Misc. 1977).

18. Khairzdah v Khairzdah, 464 So. 2d 1311 (La. Dist. Ct. App. 1985)

19. MacDonald vs. Clinger, 446 N.Y.S.2d 801 (N.Y. App. Div. 
1982).

20. Suter S. Appendix C: Case Law in Mapping Public Policy for Genetic Technologies, 1998. Accessed 10 March 2004. http://www.ncsl.org/programs/health/genetics/BOOK/appendc.htm

21. Diderikx v Cottage Hospital Corp. 393 N.W. 2d 564 (Mich Ct. App. 1986).

22. Elliott R. After Currier: Canadian Criminal Law and the NonDisclosure of HIV-Positive Status. Montreal: Canadian HIV/AIDS Legal Network, 1999.

23. Tarasoff $v$ Regents of the University of California (1974), 529 P. 2d 533 (Cal. Sup. Ct.); (1976), 551 P. 2d 334 (Cal. Sup. Ct.).

24. Miller J. Physician-Patient Confidentiality and Familial Access to Genetic Information. Health Law Journal 2:14; 1994.

25. Tanner v. Norys [1980] 4 W.W.R. 33.

26. Wenden v Trikha (1991), 116 A.R. 81; aff'd (1993), 14 C.C.L.T. (2d) 225 (Alberta C.A.).
27. Pittman Estate v. Bain (1994) 112 DLR (4th) 258 Ontario Central Division.

28. Smith v. Jones, 169 D.L.R. (4th) 385 (S.C.C.), 1999.

29. Ontario Child and Family Services Act R.S.O. 1990, c C.11.

30. Ontario Highway Traffic Act, R.S.O. 1990, c H.8.

31. The Quebec Charter of Human Rights and Freedoms, R.S.Q. C12.

32. Pate v. Threlkel, 661 So.2d 278 (Fla. 1995).

33. Safer v. Pack, 677 A.2d 1188 (N.J. Super. 1996)

34. President's Commission for the Study of Ethical Problems in Medicine and Biomedical and Behavioral Research. Screening and Counseling for Genetic Conditions. Washington DC: The President's Commission, 1983.

35. Genetics in Health Care: Report 42. Ottawa: Minister of Supply and Services Canada, 1992.

Jennifer Gold is an MPH student in Law and Public Health at Harvard University. She graduated from Law School at McGill University in 2004, where she was awarded the Thomas Shearer Student Travelling Fellowship. She also holds a Bachelor of Science in psychology from York University. Her chief areas of interest are health law/regulation and bioethics. 